cyclosporin may not greatly increase the toxicity of aggressive chemotherapy used in the treatment of haematological malignancies. Sonneveld and Nooter reported a patient with resistent AML to whom they administered cyclosporin without any excessive toxicity, although their patient had profound marrow hypoplasia for three weeks. ${ }^{9}$

Septic shock is a well recognised problem in severely neutropenic patients. It is difficult to be sure that our patient's clinical course would have been any different had he not received cyclosporin. Although cyclosporin and other inhibitors of $\mathbf{P}$-glycoprotein may improve the response to chemotherapy, the use of immunosuppressive agents during the treatment of acute myeloid leukaemia does require caution. Non-immunosuppressive cyclosporin analogues may produce the desired positive effects of P-glycoprotein inhibition without increased infection risk. ${ }^{10}$
1 Anonymous. Multidrug resistance in cancer. [Editorial]. Lancet 1989;ii:1075-6.

2 Holmes J, Jacobs A, Carter G, et al. Multidrug-resistance in haemopoietic cell lines. Myelodysplastic Syndromes and acute myeloblastic leukaemia. Br J Haematol 1989;72: 40-4.

3 Case records of the Massachusetts General Hospital. Weekly clinico-pathological exercises. Case 18-1983. A young man with pancytopenia after a renal transplant. $N$ Engl J Med 1983;308:1081-91.

4 Ellerton JA, deVeber GA, Baker MA. Erythroleukaemia in a renal transplant recipient. Cancer 1979;43:1924-6.

5 Pikler GM, Say B, Stamper S. Cytogenetic findings in acute monocytic leukaemia in a renal allograft recipient. Cancer Genet Cytogenet 1986;20:101-7.

6 Hoy WE, Packman CH, Freeman RB. Evolution of acute leukaemia in a renal allograft recipient:? Relationship to azathioprine. Transplantation 1982;33:331-3.

7 Ihle BU, Constable J, Gordon S, Mahony JF. Myelodysplasia in cadaver renal allografts: A report of four cases. Am J Kidney Dis 1985;5:251-7.

8 Butler J, Korb S, Light L. Acute myelogenous leukaemia in a renal allograft recipient receiving cyclosporine therapy. Transplantation 1990;49:813-15.

9 Sonneveld $P$, Nooter $K$. Reversal of drug-resistance by cyclosporin-A in a patient with acute myelocytic leukaemia. Br J Haematol 1990;75:208-11.

10 Twentyman PR, Fox NE, White DJG. Cyclosporin A and its analogues as modifiers of adriamycin and vincristine resistance in a multidrug resistant human lung cancer cell line. Br J Cancer 1987;56:55-7.

\title{
Inhibition of urease activity but not growth of Helicobacter pylori by acetohydroxamic acid
}

\author{
Division of \\ Gastroenterology and \\ Department of \\ Laboratory Medicine, \\ McMaster University \\ Medical Centre, 1200 \\ Main Street West, \\ Hamilton, Ontario \\ L8N 3Z5, Canada \\ J Goldie \\ $S$ Jalali \\ $\mathrm{H}$ Richardson \\ R H Hunt \\ Division of \\ Gastroenterology, \\ Dalhousie University, \\ Victoria General \\ Hospital, Halifax \\ SJO Veldhuyzen van \\ Zanten \\ Correspondence to: \\ J Goldie \\ Accepted for publication \\ 12 February 1991
}

\begin{abstract}
The in vitro effects of acetohydroxamic acid (AHA), a potent urease inhibitor, were studied to determine the effect on the urease activity and growth of 38 strains of Helicobacter pylori. AHA in concentrations of $50-1000 \mathrm{mg} / 1$ had a noticeably reversible inhibitory effect on the urease activity of the organism but no effect on growth.
\end{abstract}

Helicobacter pylori has a very high urease activity which is thought to be related to its pathogenicity, allowing it to colonise and survive in the harsh gastric environment. ${ }^{1}$

There is a need for a more effective treatment against $H$ pylori because currently available treatments are unsatisfactory. ${ }^{2}$ Acetohydroxamic acid (AHA) is a potent inhibitor of the enzyme urease..$^{3-6}$ AHA has been used in the treatment of urinary tract infections, associated with struvite stone formation, in which urea splitting organisms are important. ${ }^{7}$ AHA prevents alkalinisation of the urine by inhibiting urease, thus preventing hydrolysis of urea and subsequent production of ammonia.

The high urease activity of $H$ pylori might be inhibited by AHA and we therefore studied this in vitro to determine whether AHA inhibits urease activity and the growth of $H$ pylori.

\section{Methods}

Thirty three recent clinical isolates and five reference strains (obtained from LCDC, Ottawa) of $H$ pylori were grown microaerobically at $35^{\circ} \mathrm{C}$ for five days. Dense suspensions were made in $3 \mathrm{mmol}$ monobasic sodiumphosphate buffer $\left(\mathrm{NaH}_{2} \mathrm{PO}_{4}\right)$ containing a concentration of AHA to approximate a final concentration of $10^{8}$ organisms $/ \mathrm{ml}$ when 
compared with a McFarland 0.5 opacity standard. Parallel control suspensions of $H$ pylori with buffer but without AHA were included in each test series. The $\mathrm{pH}$ of the solutions was \pm 6 .

AHA was prepared in an aqueous solution of $10 \mathrm{mg} / \mathrm{ml}$. Dilutions were made in $3 \mathrm{mmol}$ phosphate buffer ( $\mathrm{pH} \mathrm{6.0)}$ to final concentrations of $1000,500,250,100$ and $50 \mathrm{mg} / 1$.

Twenty five microlitires of $H$ pylori suspensions in AHA solutions were inoculated into bottles containing $1.5 \mathrm{ml}$ of buffered urea solution of $\mathrm{pH} \pm 6$ (solution contains $1 \mathrm{ml}$ of Sigma urea standard solution and $49 \mathrm{ml}$ of $3 \mathrm{mmol}$ phosphate buffer). We tested urease activity in organisms that had grown microaerobically for five days rather than three days because we found the urease production to be greatest at five days. Ammonia concentrations were measured after 30 minutes at room temperature using the Kodak Ektachem chemical analyser. ${ }^{8}$ Standard crystalline jackbean urease (sigma) was used as standard. The urease activity of the AHA solutions ( $\mathrm{nmol} /$ residual $\mathrm{NH}_{3} / \mathrm{l}$ ) was compared with control suspension without AHA, and background activity of ammonia was substracted. The average results of three to five experiments per strain are shown (table). The coefficient of variation of this method was $4 \%$. Urease activity of the suspensions was also checked after four and 24 hours using our own rapid urease test. ${ }^{9}$

Subcultures were made after 24 hours from the inoculated AHA suspensions and control suspensions using chocolate agar and buffered peptone medium with $5 \%$ horse serum. Both media were at $\mathrm{pH} 7 \cdot 0$. Each was incubated microaerobically for five days.

\section{Results}

The table shows that AHA inhibited the urease activity of $H$ pylori. The highest level of inhibition occurred with AHA concentrations of $200-1000 \mathrm{mg} / \mathrm{l}$ and as there were only minimal differences among strains the average result for each AHA concentration is shown. The inhibition of urease is only temporary because results of the rapid urease test were positive again after 24 hours. AHA did not affect the survival of the organism.

\section{Discussion}

The results show that AHA is a potent inhibitor of the urease activity of $H$ pylori but

Results of average residual ammonia production, rapid urease test, and growth of suspensions containing only $H$ pylori and suspensions containing the organism with $A H A$

\begin{tabular}{|c|c|c|c|c|}
\hline \multirow[b]{2}{*}{ Suspension } & \multirow{2}{*}{$\begin{array}{l}\text { Average } \mathrm{NH}_{3} \\
\text { production in } \\
\text { in } \mu \text { mol/l }(S D)\end{array}$} & \multicolumn{2}{|c|}{ Rapid urease test } & \multirow{2}{*}{$\begin{array}{l}\text { Growth of } \\
\text { H pylori }\end{array}$} \\
\hline & & 4 hours & 24 hours & \\
\hline $\begin{array}{l}\text { All } \mathbf{H} \text { pylori suspensions } \\
\text { without AHA }\end{array}$ & $>900$ & + & + & + \\
\hline AHA $1000 \mathrm{mg} / \mathrm{l}$ & $41(8)$ & - & + & + \\
\hline $\mathrm{AHA} 500 \mathrm{mg} / \mathrm{l}$ & $31(6)$ & - & + & + \\
\hline AHA $250 \mathrm{mg} / \mathrm{l}$ & $25(6)$ & - & + & + \\
\hline AHA $200 \mathrm{mg} / \mathrm{l}$ & $23(7)$ & - & + & + \\
\hline AHA $100 \mathrm{mg} / \mathrm{l}$ & $152(39)$ & - & + & + \\
\hline $\mathrm{AHA} \cdot 50 \mathrm{mg} / \mathrm{l}$ & $200(48)$ & - & + & + \\
\hline
\end{tabular}

that inhibition is reversible and does not affect the growth of the organism. We wanted to study urease activity during optimal growth conditions of the organism, which is at $\mathrm{pH} \pm 5 \cdot 0-8.0$ and is adversely affected by lower $\mathrm{pH}$. Because the organism lives in the gastric mucus where the $\mathrm{pH}$ is neutral, these studies were performed at a $\mathrm{pH}$ of 6-7.

The characteristic high preformed urease activity of $H$ pylori is considered important for its pathogenicity. Pathophysiological mechanisms that have been proposed are hydrogen ion back-diffusion ${ }^{10}$ and interference with the trichoracetic acid cycle. The latter results in a decreased production of adenosine triphosphate (ATP) in aerobic cells which may inhibit normal cell function. ${ }^{11}$ Furthermore, urease activity allows the organism to use urea as an important nitrogen source.

The urease of $H$ pylori differs from other strong urease producers such as Proteus mirabilis in showing much higher affinity for urea and higher activity of the enzyme, which may be necessary for the survival of the organism as urea is less available in the gastric mucus than in urine. ${ }^{1}$

Although initially AHA was believed to cause irreversible inhibition of urease activity, ${ }^{3}$ later studies, which are confirmed by our study, show that inhibition is temporary. ${ }^{12}$ The inhibitory effect of AHA is highly specific for urease. $^{6}$ The optimal $\mathrm{pH}$ of the urease activity is about $8 \cdot 2^{1}$ and corresponds to optimal growth conditions of $H$ pylori. (Goldie J, Hollingsworth J, Hunt RH. Campylobacter pylori multidisciplinary workshop, Keystone, Colorado, 1987). Hydroxamic acids probably do not have clinically important antimicrobial activity, although one report indicates that AHA is bacteriostatic against several bacteria. ${ }^{413}$ In vitro, both synergy and antagonism have been found when AHA was combined with other antibiotics against Gram negative urease producing organisms. ${ }^{413}$ Furthermore, synergism may be $\mathrm{pH}$ dependent, which may be relevant for $H$ pylori, given that the organism must establish itself in the acidic environment of the stomach. ${ }^{13}$

The mechanism by which AHA inhibits urease is unknown, but because growth is not inhibited it does not inactivate the whole organism. Possible mechanisms include inhibition of enzyme activity or enzyme synthesis, or blocking contact of the enzyme with the substrate urea. It has been shown that the cell wall of the organism is no barrier for AHA. ${ }^{1}$

Our results suggest that AHA when used alone will not result in eradication of the organism because growth is not affected. Inhibition of the urease activity, however, could have an adjuvant therapeutic role in the treatment of $H$ pylor $i$ by making the organism more susceptible to other antimicrobial agents. Side effects may occur with AHA in up to $30 \%$ of patients and include bone marrow depression, Coombs' negative haemolytic anaemia, deep vein thrombosis and thrombophlebitis. ${ }^{7}$ These occurred when AHA was 
given in high doses of $15 \mathrm{mg} / \mathrm{kg}$ for at least one year. Although toxicity may be less if given in a lower dose for a short period of time, caution must be exercised when considering AHA as a suitable agent for clinical use in the treatment of $H$ pylori.

1 Mobley HLT, Cortesia MJ, Rosenthal LE, Jones BD. Characterisation of Urease from Campylobacter pylori. $J$ Clin Microbiol 1988;26:831-6.

2 Hirschl AM, Pletschette M. Antibiotic treatment of Campylobacter pylori infection. In: Rathbone BJ, Heatley RV, eds. Campylobacter pylori and gastroduodenal disease. Oxford: Blackwell Scientific Publications, 1989:217-24.

3 Fishbein WN, Carbone PP, Hochstein HD. Acetohydroxamate: bacterial urease inhibitor with therapeutic poten-

4 Gale GR. Urease activity and antibiotic sensitivity of bacteria. J Bacteriol 1966;91:499-506.

5 Wolpert E, Hofmann AF, Summerskill WHJ. Synthesis and Metabolism of labeled acetohydroxamic acid, a urease Metabolism of labeled acetohydroxamic acid, a
inhibitor. Proc Soc Exp Biol Med 1971;136:592-6.

6 Kobashi K, Takebe S, Terashima N, Hase J. Inhibition of urease activity by hydroxamic acid derivates of amino acids. J Biochem 1975;77:837-43.

7 Williams JJ, Rodman JS, Petreson CM. A randomised double-blind study of Acetohydroxamic Acid in struvite nephroithiasis. N Engl J Med 1984;311:760-4.

8 Kodak Ektachem Clinical Products Division. Ammonia test Methodology. Rochester, New York: Eastman Kodak, 1985 .

9 Goldie J, Veldhuyzen van Zanten SJO, Jalali S, et al. Optimization of a medium for the rapid urease test for Optimization of a medium for the rapid urease test for detection of Campylobacter pylori in gas
sies. J Clin Microbiol 1989;27:2080-2.

10 Hazell SL, Lee A. Campylobacter pyloridis, urease, hydrogen ion back diffusion, and gastric ulcers. Lancet 1986;ii:15-17.

11 Tytgat GNJ, Axon ATR, Dixon MF, Graham DY, Lee A, Marshall BJ. Helicobacter pylori: Causal agent in peptic ulcer disease? Working Party Reports 1990. World Congress of Gastroenterology, Sydney August 1990. Melbourne: Blackwell Scientific Publications, 1990:36-45.

12 Fishbein WN, Daly JE. Urease inhibitors for Hepatic Coma. II. Comparative Efficacy of four lower Hydroxamate homologs in vitro and in vivo. Proc Soc Exp Biol Med 1970;134:1083-90.

13 Musher DM, Saenz C, Griffith DP. Interaction between Acetohydroxamic Acid and 12 antibiotics against 14 Acetohydroxamic Acid and 12 antibiotics against 14 Gram-negative pathogenic
Chemother 1974;5:106-10.

\title{
Detection of Helicobacter pylori carriers by discriminant analysis of urea and $\mathrm{pH}$ levels in gastric juices
}

\author{
F Ameglio, M R Abbolito, D Giannarelli, F Citarda, A Grassi, G M Gandolfo, V Casale
}

Laboratory of Clinical Pathology, Regina Elena Institute for Cancer, Viale Regina Elena 291, 00161 Rome, Italy F Ameglio

M R Abbolito

D Giannarelli

G M Gandolfo

Service for Digestive Endoscopy, Regina Elena Institute for Cancer Research F Citarda A Grassi $\checkmark$ Casale

Correspondence to: Dr F Ameglio

Accepted for publication 12 February 1991

\begin{abstract}
An alternative approach to the problems inherent in current methods for detecting Helicobacter pylori carriers-that of being generally time-consuming, expensive, and not sufficiently sensitive-was devised by using the urea concentration and $\mathrm{pH}$ levels of gastric juices. A linear discriminant analysis of these variables, measured in 54 patients submitted to digestive endoscopy for gastritis, provided a mathematical formula for assigning the subjects (previously classified by other standard methods) to groups of either positive or negative $H$ pylori carriers. The results obtained showed a correct classification in 52 out of 54 cases with only one false negative and one false positive case.
\end{abstract}

Before starting treatment for Helicobacter pylori infection, frequently associated with dyspeptic symptoms, an early and reliable diagnosis must be made. ${ }^{12}$ The urease test performed on histological specimens, considered valid because of its rapidity, low cost, and easy execution, is not very sensitive: only $62 \%$ of positive cases are detected in our laboratory compared with other tests such as culture and microscopical examination of biopsy specimens, brushings, and pellets of gastric juices. ${ }^{3}$ This report proposes an alternative approach to the problem based on the use of the discriminant analysis of the urea concentrations and $\mathrm{pH}$ in gastric juices.

\section{Methods}

Fifty four samples of gastric juice, obtained from patients submitted to digestive endoscopy for gastritis (29 men and 25 women, mean (SD) age $48.3(5 \cdot 7)$ years), were analysed by standard cultural and microscopic methods to identify the presence of $H$ pylori. The same samples were tested for urea (Beckman: ASTRA 4, Automated Stat/Routine Analyzer with the urea kit from the same manufacturer) and $\mathrm{pH}$ concentrations ( $\mathrm{pH}$ meter).

For the statistical analysis of the data, a discriminant analysis was used (7M module of the BMDP Statistical Package), which allows individual patients to be assigned to different groups, previously classified by another reference system. ${ }^{4}$

\section{Results}

Thirty one of 54 biopsy specimens were 